\title{
Adriaan Reland on Islamic Gems and Seals
}

\author{
An Annotated Translation of the Latin Text
}

Jan Just Witkam

\section{Introduction $^{1}$}

In 1708, Adriaan Reland (1676-1718), professor of Oriental languages at the University of Utrecht, published a short treatise on Islamic gems and seals. Rather than a theoretical essay, it was a number of short case studies based on seals that were shown to him by Dutch contemporary collectors, owners of cabinets of curiosities. Reland uses the texts on the seals to reiterate positive aspects of Islam, in particular its extreme monotheism. He had previously made these points in his thesis of 1696 and his study of Islam, the first edition of which had appeared in 1705. The essay on seals also gives us a glimpse of Reland's extensive social network.

Adriaan Reland's short treatise on Islamic seals of $1708,{ }^{2}$ which seems to be the first of its kind, can be read from two perspectives. First, there is the small corpus of seven Islamic seals that Reland presents and deciphers. He uses the texts of a number of 'his' seals to show that there are ideas in Islam that are not so different from Christianity, especially the notion of monotheism. This is a recurrent theme in Reland's writings, especially his doctoral dissertation ${ }^{3}$ and his much larger work on the 'Muhammadan' religion (first edition 1705, second edition 1717). ${ }^{4}$ This is how we know Reland, as a proponent of 'a more balanced and tolerant view of Muhammad and his religion', as a protagonist of the early Dutch Enlightenment. ${ }^{5}$ A sub-theme in the treatise on seals is Reland's criticism of the Arabic typography of his time, which he finds poor in comparison

1 This chapter follows my presentation at the Colloquium 'Adrianus Relandus (17 July 1676-5 February 1718), Professor Oriental Languages, University of Utrecht 1701-1718', Utrecht, 5 February 2018, which can be seen here: $<$ http://islamicmanuscripts.info/Files/Witkam-2018 -Reland-Islamic-seals.pdf>.

2 Reland, 'Dissertatio De gemmis Arabicis', pp. 231-250.

3 Reland, Exercitatio philologico-theologica.

4 Reland, De religione Mohammedica.

5 Israel, Enlightenment Contested, p. 615. See also Hamilton, 'From a "Closet at Utrecht". 
with the calligraphic potential of the Arabic script that we see in manuscripts and inscriptions [Fig. 13.4].

The second perspective concerns the social context of the author. Given that, when Reland wrote, there were only private collections of exotic objects such as Islamic seals in the Netherlands, I have tried to find out who these 'collectionneurs' with an interest in seals were, what their relationship with Reland was, and how the relevance of their collections can be understood in the context of their time. About Henricus Hadrianus vander Marck and Jacob de Bary I could at least find some information. I have been more successful in the case of Jacob de Wilde.

Reland calls the 'seals' that he describes gemmae, 'precious stones'. A more particular meaning of the word is 'things made of precious stones', among which can be understood 'a seal ring, a signet', a 'pearl', and 'the eyes in a peacock's tail. ${ }^{6}$ However, only one of the gemmae is explicitly described by Reland as being made of a precious stone, an agate (No. 1), and only one was meant to be printed and was therefore a genuine seal (No. 6). All the illustrations in Reland's short study are unsigned copper engravings, the original drawings of which could have been made by Reland himself as he was also an accomplished draughtsman.

Like several other of his shorter treatises, Reland wrote his essay on Islamic gems and seals in the form of answers to questions from several friends and acquaintances. As is often the case with those who know how to read nonLatin scripts, he was asked by several members of the public about pieces in their collection. ${ }^{7}$ Of the seven pieces that he treated, he was only the owner of the last one (No. 7). The other seals belonged to Dutch patricians, Jacob de Bary (d. 1727, Nos. 1, 2, 5), Jacob de Wilde (1645-1721, No. 3) and Henricus Hadrianus vander Marck (d. 1727, No. 4). No. 6 is not given a provenance, but it appears to originate from India, not from Indonesia. Reland interpreted the language on the seal as Malay, but it could also have been Sanskrit. Three collectors asked Reland for information:

Henricus Hadrianus vander Marck, who probably died in 1727 , was a Catholic clergyman and a private collector. His library and huge coin collection were auctioned off in The Hague on 14-22 July 1727 and later by the bookseller

6 Lewis and Short, $A$ Latin Dictionary, s.v.

7 My own professor of Arabic, Jan Brugman (1923-2004), in his first course in October 1964, mockingly announced to us a future of deciphering fragmentary texts in Arabic scripts on ashtrays, wrappers of all sorts, Coca Cola bottles, etc. 
Petrus de Hondt. I have no further information on him nor is his auction catalogue of 1727 explicit about his life and work. ${ }^{8}$

Jacob de Bary was a collector of coins and other curiosities. He had lived in Seville as a consul to the Dutch nation and in 1702 he had moved to Amsterdam. In 1727 he died in Maarseveen. ${ }^{9}$ The auction of his collection was scheduled, according to the title-page of the catalogue, in aedibus defuncti ('in the house of the deceased') in April or May $1730^{\circ}{ }^{10}$ In his treatise on Islamic seals Reland calls De Bary's cabinet of curiosities 'Cimeliarchum Barianum', the 'Baryan Treasury'.l The auction catalogue shows in two separate images and twenty-six tables a modest collection of some 139 items, mostly Roman and Phoenician coins, but also thirteen Islamic coins, gems or seals, including the three that Reland described in $1708 . .^{12}$

From the introduction to the auction catalogue, the fact that De Bary collected most of his seals or gems in Spain where he had lived for a long time and where he had owned a magnificent mansion, is confirmed. The three seals of De Bary's collection that Reland describes (Nos. 1, 2 and 5) are also illustrated in the auction catalogue. The inscriptions of Nos. 1 and 2 are given in Latin translation in the beginning of the catalogue. These were apparently copied from Reland's treatise on Islamic gems and seal. The three illustrations in the auction catalogue of 1730 are based on the same copper engravings that Reland

8 Van der Marck, Bibliotheca. His numismatic collection of Greek and Roman coins was described in a separate sales catalogue in two volumes: Van der Marck, Series numismatum antiquorum. His Shi'ite seal, Reland's No. 4, is not mentioned in the auction catalogue. The auction catalogue of 1727 describes him on its title-page as: 'Toparcha in Leur, \& Ecclesiae Metropolitanae, quae Ultrajecti est, Canonicus, \&c. \&c.', meaning 'Seigneur' of Leur (a locality in Brabant, now part of Etten-Leur) and Canon (Clergyman) of the Metropolitan Church in Utrecht, etc. The website of the Netherlands Institute for Art History in The Hague (RKD, Rijkskunsthistorisch Documentatiecentrum), with reference to the 1727 auction catalogue, calls van der Marck a 'publisher' and a 'book collector' < https://rkd.nl/nl/explore/artists/467342>. See also the Biblissima website $<$ https:// portail.biblissima.fr/>, which offers a virtual library of texts and books produced and described between Antiquity and the eighteenth century, and which contains a description of the items in van der Marck's library.

9 Schutte, Repertorium, p. 411.

10 De Bary, Catalogus numismatum antiquorum. I am grateful to Paul Dijstelberge, Amsterdam University, for putting photographs of this rare booklet (copy: Amsterdam University Library, Obr. oo5 267) at my disposal.

11 Reland, 'Dissertatio de Gemmis Arabicis', p. 248.

12 Table 22 shows a display of eleven Islamic coins. Nos. 1-5 and No. 11 give the impression of being early, possibly Umayyad coins, with the Islamic creed as text. No. 6 is the item that Reland described as his No. 5. De Bary's No. 7 was struck in Granada in 89o (1485-1486), and his Nos. 8 and 9 possibly as well, in $880\left(1475^{-1476}\right)$ and $890\left(1485^{-1486)}\right.$ respectively. The origin of De Bary's No. 10 is not clear. 
had used in 1708. No. 5 is illustrated in the auction catalogue (table 22, No. 6), together with a number of other coins with legends in Arabic, but these latter were commented upon by Reland. Jacob Diego de Вагу had been appointed Dutch consul in Seville on April 8, $1689 .{ }^{13} \mathrm{He}$ is also mentioned in a letter from Gisbert Cuper (1644-1716) to Gottfried Wilhelm Leibniz (1646-1716), dated Deventer, February 1711. Among other things Cuper tells Leibniz that De Bary spent some twenty years in Seville as a consul, looking after the interests of the Dutch merchants there, and that he owned a collection of some eight hundred coins. ${ }^{14}$ In his Bibliothèque choisie Jean le Clerc (1657-1736) in two instances mentions objects from De Bary's cabinet, ${ }^{15}$ first a number of Phoenician coins, ${ }^{16}$ then a piece of nonflammable wood. ${ }^{17}$ From this we may conclude that the cabinet also contained naturalia.

Jacob de Wilde $\left(1645^{-1721)}\right.$ is the acquaintance of Reland about whom we know most. He was a high official ('ontvanger-generaal') in the Admiralty of Amsterdam. He himself has left few traces in the biographical literature, and what we know about him often comes through publications by or about his daughter Maria de Wilde (1682-1729), a highly versatile young woman who was active as an engraver and playwright in Amsterdam's upper-class bourgeoisie [Fig. 13.1]. In a poem by Pieter van den Berge (1659-1737), her publisher and himself a man of many talents, which prefaces one of Maria's tragedies, the cabinet of curiosities of her father is described:

The cabinet of Mr. de Wilde is famous all over Europe, because knowledge can be acquired here free of charge by everybody who decides to look for wisdom. This is because De Wilde provides for excellent intellects a flat and smooth track that leads to the knowledge of peoples and countries, which are then led to Pallas's choir. Here you see, in the form of collections of coins, old customs, their temples so rich and great, their funerary pillars after their death, their palaces now fallen into ruin, their sacrifices,

\footnotetext{
13 Schutte, Repertorium, p. 411.

14 Leibniz, Sämtliche Schriften und Briefe, pp. 41-42 (No. 32).

15 See about this journal Wijngaards, De «Bibliothèque Choisie».

16 Le Clerc, Bibliothèque Choisie, vol. 11 (1707), article 2 (pp. 104-133). In the illustration opposite p. 104 several Phoenician coins can be observed that would later also occur in De Bary's auction catalogue of 173 .

17 Le Clerc, Bibliothèque Choisie, vol. 12 (1707), article 2 (pp. 57-8o), and see also the beginning of the Avertissement of the same volume.
} 
their victories, their splendour, their delightful jewelry, their loot, their playful festive dressings ... All this De Wilde shows to you....18

The same Pieter van den Berge has drawn a portrait of Jacob de Wilde as the frontispiece of a printed catalogue of part of his collection of gems [Fig. 13.2]. One sees him in his Museum, holding a tray from a dactiliotheca with gems in his left hand. ${ }^{19}$ The cabinet, the Museum Wildianum as it was called, was a large room in De Wilde's house at Keizersgracht 333, Amsterdam. The walls are covered with shelving that contains books, plano leaves, and globes. ${ }^{20} \mathrm{~A}$ large number of statuettes are placed on top of the shelvings. ${ }^{21}$ At the far end of the room is an apse ${ }^{22}$ in which De Wilde's Nummophylacium was placed, an artfully made container for choice items from his collection of coins. In the centre of the room is a round table. It shows De Wilde sitting with his royal visitor, Czar Peter the Great (1672-1725), who visited the Museum on December 13, 1697 [Fig. 13.3]. On the table are several smaller objects the function and nature of which seem to be the subject of conversation.

We are so well informed about the room because of an etching by Maria de Wilde. She had made a drawing on the date of the visit of Czar Peter and she subsequently made an etching of it that illustrated the catalogue of $1700 .{ }^{23}$ That catalogue also contains an engraved portrait of Maria de Wilde herself, made by David van Hoogstraten who added a short poem in Latin. There are

18 My translation from the Dutch text of the beginning of the liminary poem by Pieter van den Berge preceding Maria de Wilde, Abradates en Panthea, unnumbered page. The love story of Abradates and Panthea is a theme developed by Xenophon in his Cyropaedia.

19 [De Wilde], Gemmae selectae antiquae. An uncatalogued copy of the portrait is in Leiden University Library: Singer 33543.

20 Of the two globes that the cartographer Willem Jansz. Blaeu (1571-1638) produced from 1602 onwards, one represented the earth, the other the sky.

21 It is tempting to identify these with those depicted by Maria de Wilde in [De Wilde], Signa Antiqua.

22 Details of the Nummophylacium can be seen in four unnumbered engravings at the end of another De Wilde catalogue, Selecta Numismata Antiqua.

23 [De Wilde], Signa Antiqua. The edition has several 'drempelgedichten' (liminary poems). One of these is a poem in Latin by Charles Heriot of King's College, Cambridge in praise of the Nummophylacium and its content under the motto non equidem invideo, miror magis, 'I am not envious of something like this, I rather admire it'. A similar poem by David van Hoogstraten (1658-1724) is there as well, as is a poem by Andreas Lange (1680-1713) from Lubeck on De Wilde's Gazophylacium, 'treasure chest'. Andreas Lange (Andreas Langius), a lawyer, poet and literary translator from Lübeck, fell in love with Maria de Wilde but this led nowhere. A Dutch translation by Johannes Brandt (1654-1731) of his now lost Latin love poem to Maria de Wilde is in Kaspar and Johannes Brandt, Poëzy, vol. 2, pp. 61-62. Judging by the translation it is clear that Lange's desires for Maria de Wilde, both spiritual and physical, were expressed in unequivocal terms. 
several more of these 'liminary poems' in this and the other De Wilde catalogues, all praising the Museum. Reland's poem, however, does not concern the Museum, but rather what may have been De Wilde's greatest treasure by far, his daughter Maria. In 46 elegant hexameters, he describes Maria's art and beauty. 'You paint Venus in such a way that if the sculptor Apelles would see it, he would say: this art is not less than mine'. And about her physical qualities he addresses her: 'It is credible, most beautiful virgin, that marble (statues) become soft when you touch them'. Neo-Latin lyrics were no uncharted territory for Reland, as can be seen from his poetical play Galatea. ${ }^{24}$ Having cabinets of curiosities as Jacob de Wilde did was a hobby among the rich bourgeoisie in the Netherlands. ${ }^{25}$ Reland used his own manuscript collection as a source for his learned commentary on the gems that he was asked about. These bibliographical references can be found in the 'Index' of both editions of $D e$ religione Mohammedica $(1705,1717)$. A full view of the considerable collection of manuscripts that Reland had brought together during his short life can be gained from the auction that was held after the demise of Reland's son Jan Hubert Relandt on April 6, 1761, and the days following. ${ }^{26}$

\section{$2 \quad$ Translation of Adriaan Reland's Essay on Islamic Seals ${ }^{27}$}

[p. 231] Essay 13 on Islamic seals [p. 232 blank]

[p. 233] Essay 13 on Islamic seals

\section{$\S 1 \quad$ On the Use of Arabic Seals}

I am very much aware of the fact that there are quite a number of people who are eager to acquire certain precious seals, and that, among them, they prefer to look for seals with Arabic or Persian inscriptions. So, for the pleasure of those who are desirous to read and understand the Oriental pieces, and to

24 Reland, Galatea, which was reprinted (1710, 1739), annotated (1809) and translated into Dutch (1837). See also the article by Dirk Sacré in the present volume.

25 See for an overview Bergvelt and Kistemaker (eds), De wereld binnen handbereik. Jacob and Maria de Wilde are abundantly mentioned in this book, but Jacob de Bary and Henricus Hadrianus vander Marck remain unmentioned.

26 Naam-lyst van een zeer keurige verzameling ... boeken met daarin de Catalogus codicum manuscriptorum (1761). I consulted the annotated copy of this auction catalogue that is kept in the collection of the 'Vereeniging ter bevordering van de Belangen des Boekhandels', now Amsterdam, University Library, кVв Nv 274. I am grateful to Arnoud Vrolijk (University Library, Leiden) for providing me with images of this catalogue.

Reland, 'Dissertatio De gemmis Arabicis', pp. 231-25o. Footnotes are by me, not by Reland. 
solve the complex and intricate difficulties of the script, I will show several seals to which I will add my interpretation. Those specialists of Arabic and Persian, who devote themselves [p. 234] to reading manuscripts, more in particular Persian ones, or who occupy themselves with numismatics or epigraphy, will agree with me that this is a useful activity. Even if the small specimen that we herewith present is in no way sufficient to overcome all difficulties, it will nevertheless lead to something. Especially so if the information that I have recently published ${ }^{28}$ about the four Arabic inscriptions that are, even today, available in Pozzuoli is added to this.

Nor will those who are not knowledgeable about these secrets be totally ungrateful for this work, unless I flatter myself with a totally vain imagination. Who, then, is not taken in by looking at scripts so elegant and artful, which show ornate interconnected letters, with the correct application of spaces and with the distribution of diacritics that look like little stars? And all these, I confess, are the more accurately perceived by the person to whom these letters are not unknown. To the uneducated person, they even show that these peoples, from whom these scripts originate, are not as uncivilised and barbaric as we are generaly inclined to believe.

\section{$\S 2 \quad$ Explanation of the First Seal}

The first seal, which is kept in the Treasury of the Most Noble Gentleman, Jacob de Bary, is the one that is shown on the next page. I have described it at the request of this gentleman, who is my very good friend, and these writings have previously been published. However, as they have only reached very few hands, ${ }^{29}$ I will explain them here once more for the reader. These are the writings: [p. 235]

28 For the Arabic inscriptions of Puzzuoli (near Naples) see Reland, De nummis veterorum Hebraeorum, appendix pp. 1-16, apparently published under a separate title: Adriani Relandi Dissertatio de marmoribus Arabicis Puteolanis et nummo Arabico Constantini Pogonati. The latter title had been published earlier as a separate booklet by Theodor and Henricus Bruyn in Amsterdam. It is in fact an informative letter addressed to Didericus Modé, dated Utrecht, October 1, 1704. In this Dissertatio Reland gives a transcription and a Latin translation of the four inscriptions in Puzzuoli and shows No. 3 in his illustration. All four inscriptions had already been illustrated by Sarnelli, La guida de forestieri curiosi, published in Naples in 1697. In the edition of 1709 that I consulted, the four inscriptions are illustrated together opposite p. 28. For a modern study on these inscriptions, see Grassi, 'Iscrizione funerarie arabe nel Napoletano'. These Italian references were kindly provided by Lucia Raggetti (Bologna University), to whom I am most grateful. Is this a reference to another work of Reland or to one of his letters? 


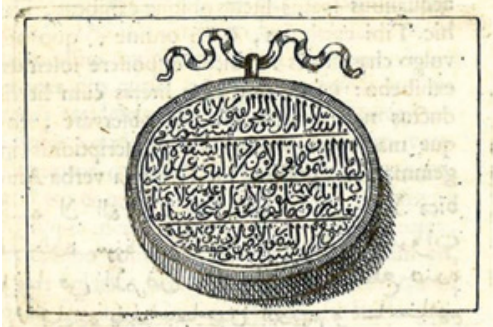

Reland, seal 1.

\section{Adriaan Reland to the Most Noble Gentleman Jacob de Bary}

My dear friend, it rarely happens that I leave Amsterdam without your blessing me with some small handful, according to the custom of Oriental peoples. In this case, a few days ago, you were so kind as to give me an example of this when you wished to hand over this Agate to me, inscribed with Arabic script, in order to be examined. I herewith return it to you, in the hope that I have sufficiently satisfied your wish when you requested me to decipher the script. Since the script lines are wonderfully intricate, as if the initial letters of one word were sometimes placed on top of the other and sometimes underneath the other in order to enhance the script's elegance, so that the total surface of the seal everywhere shows letters with equal proportions, [p. 236] I shall present them to you in extricated (?) form and in the order in which we usually use the Arabic characters. In such a way that you can observe that the script lines in which the letters are placed together are not very different, and so that you can better admire the artfulness of the script in your seal. Here, then, are the Arabic words themselves:

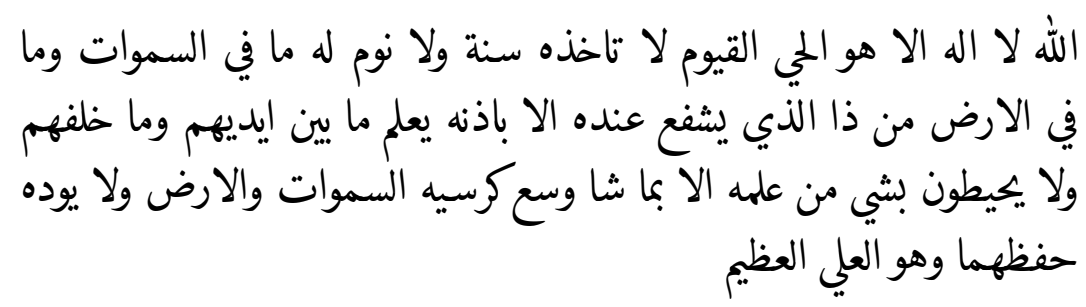

In Latin, these words sound as follows: ${ }^{30}$ 'God. There is no God besides Him. He is the Living One, the Everlasting One. Slumber does not overtake Him, nor sleep. To Him belongs what is in the heavens and what is on earth. Who is it who can intercede with Him other than by His permission? He knows what is

30 Qurān 2:255. Here directly translated by me from Arabic into English. Reland translates 'He knows what is in front of them and what is behind them' with 'He knows the present and the future'. See also Fig. 13.4. 
in front of them and what is behind them, and they do not comprehend anything of His knowledge except what He wishes. His throne extends over the heavens and the earth. The preservation of these two does not tire Him, and He is the High One, the Great One'. 'What an excellent description', you will say, 'of the divine omnipotence and majesty!' Thus it is, Most Noble Gentleman, [p. 237] and you would admit this all the more if you understood the text in Arabic. Yet I doubt whether this can be explained to certain people who take all Muhammadans for donkeys. The more so if I had told you that all these words are contained in the most holy Qur'ann. And that is the truth. They can be read in the second chapter, in verse two hundred and fifty-six. ${ }^{31}$ However, may these pericopes alone convince the people, who are of the opinion that the Qurān only contains trivialities and nothing useful, of the contrary. If they had been transmitted by a Greek or Roman author they would have been highly praised. But now that they have been said by Muhammad, they are not deemed worthy of review or attention. So much for the prejudices about the barbarism and stupidity of the Turks! It would be more useful if they were more concerned with the conversion of these peoples to the Christian faith, and that they spent hours learning the Arabic language, which is useful for other reasons as well, and reading the theological scriptures of the Muhammadans (if it has to be that God whose effort some of us would wish to use for the salvation of so many erring peoples), than to speak about them with contempt, to neglect their languages, and to vituperate against the efforts of a few people devoted to these matters. Really, I feel that I have already exhausted the subject. You, who have direct knowledge of the Muhammadans of Africa when you lived in Spain, [p. 238] are used to judging them in a softer and more benign way. May God keep You for a long time intact and well-preserved, so that you can show to the world of learning, according to your decision, those excellent and remarkable coins, of Phoenician and Celto-Iberian origin, and the other most rare inscriptions (with which you can provoke the envy of Princes, Kings, and the owners of numismatic treasuries), and that you add the well-deserved value of your effort to them. Thus, written in Utrecht on July 26, 1706.

\section{§ 3 A Qur'änic Passage Contains Something Excellent}

I have nothing to add to what I have just written above, except that I saw in the Bibliothèque Orientale by that most erudite author, Barthélemy d'Herbelot, under the lemma 'Corsi', that this Qur'annic passage is reckoned by the Muhammadans to be among the most excellent passages of the Qur'àn, and

$31 \quad$ Verse 255 according the Cairo vulgate edition. 
that especially the last passage is praised as the most elegant one. ${ }^{32}$ This is what d'Herbelot writes [in French]: 'In the second chapter of the Qur'ān it is said that the Throne of God embraces heavens and earth, that the preservation of these does not require any effort of Him, since he is the Highest One, the Greatest One [...]. The exegetes tell us that this verse is the most considerable of the entire Qur'ān, and that reading it therefore brings the greatest blessings.'

\section{§ 4 The Second Seal Contains the Same Text}

The second seal, which later reached the hands of the same person whom we have mentioned before, and then my own hands, is the following: [p. 239]

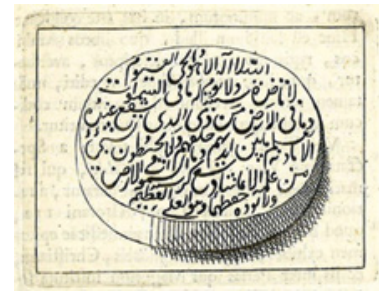

Reland, seal 2.

That seal contains the same pericope of the Qurān as the first one, but it is executed in a different style. It will not strike those who know the Arabic script as unpleasant to compare the characters of this seal with those that can be read in the first seal and to admire the elegant variety in which the same letters and words are written so that they do not seem to have anything in common, either on first view, or after a more accurate study. But these are the treasures of the Orient. These are the signs of rich penwork and a fertile imagination of the Asiatic peoples, who know how to vary one and the same character in more than one most artful script, and who organize a sizeable part of the ornamentation of their books, and equally their correspondence, [p. 240] with seals and coins in this way. Hence the disgust with which they turn away from the Arabic books that are printed in our way. These books may have been very accurately edited, but in no way do they approach the elegance of the manuscripts that are in use in the Orient.

\section{§ $\quad$ Chapter 112 of the Qur'ān Inscribed on a Seal}

The third seal, which has been given to me by the Excellent Gentleman Jacob de Wilde, who is Treasurer-General at the Admiralty of Amsterdam, ${ }^{33}$ con-

32 D'Herbelot, Bibliothèque orientale, p. 274.

33 Thus in Zuidema, 'Maria de Wilde'. 
tains chapter 112 of the Qurān. It gives a short epitome of the Muhammadan doctrine, directed against the Jews, the Christians, and those Persians who follow the ideas of the Magi. First, it teaches us that their God is One God, and that He is eternal. The word الصمد is translated in various ways: as 'eternal'; 'permanent'; the 'One to Whom all our actions must be directed as if He were the goal'; the 'One Who exists by Himself; and Who is lacking nothing in order to exist, but Whom all things are in need of'. That is the power that is inherent in this word, write the Muhammadans. However, the Greeks, who were among the first to attack this religion in writing, have mistranslated this word

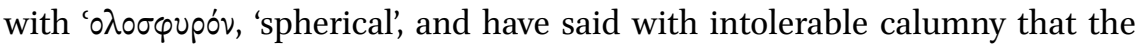

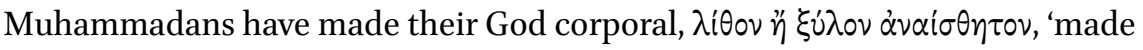
out of stone or wood', as if these very words and their derivatives are always used for solid and hard objects. But I will certainly not dwell [p. 241] on this and I have effectively responded to this calumny elsewhere. ${ }^{34}$ In the same chapter of the Qurān, which is shown in the third seal, Muhammad writes against the Jews, who, he said take Ezra, that is 'Uzayr, as the son of God, that God has no offspring; against the Christians, who believe that Christ was born from God the Father, that God is no offspring (about which Johannes Damascenus

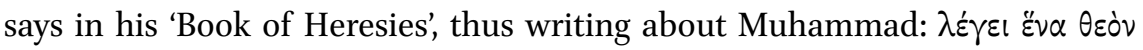

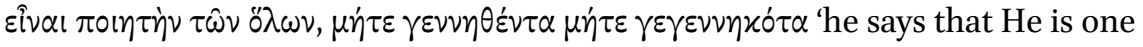
God, the Maker of everything, Who has no offspring and Who is no offspring'); ${ }^{35}$ against the Magi, finally, who believed in two equal principles, good and bad, and against some Arabs, who declared that God has associates, [he writes] that nothing is equal to Him. On page 410 is the image of the seal itself.

34 It is, in fact, the main subject of Reland's doctoral thesis of 1696, Exercitatio philologicotheologica, in particular thesis IV on pp. 7-8. Reland repeated the discussion in $\S 3$ of book 2 of the first edition of his De religione Mohammedica, pp. 105-110.

35 Greek text (after Migne) with English translation in Sahas, John of Damascus on Islam, pp. 132, 133. 


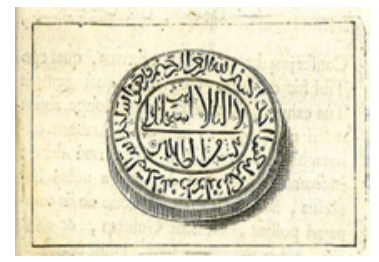

Reland, seal 3 .

\section{§ 6 Explanation of the Third Seal}

What I have written not long ago to the Excellent Gentleman De Wilde as explanation of this seal I will also offer here to the eyes of the readers. Here, then, is my letter. [p. 242]

\section{Adriaan Reland to the Excellent Gentleman Jacob de Wilde}

I herewith return to You the Arabic seal that I brought here with me yesterday from Amsterdam, together with the explanation of the characters that it contains. The two lines that are visible in the central part of your seal are as follows, in the Arabic typography as used by the Christian printers:

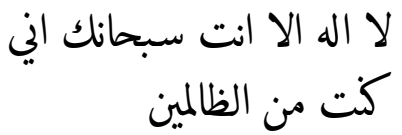

Compare now the form of these letters, that I herewith offer to you, with those that are shown in your seal, and you will see how far our printers are from the extraordinary Arabic calligraphy. This to such an extent that it should not appear strange that the Muhammadans appreciate less the books in Arabic script that are printed among us, such as the Gulistān by Sa'dī and others, and by far prefer to these the books that have been written by hand. You will also understand, when you compare these characters, that the different words are actually joined, and that some are placed on top of others, so that the tail of the letter in the word اني has a backward extension in such a way [p. 243] that it serves as a separation line in the central part of the seal. Translated into Latin [and here into English] these words are: 'There is no God except You. Praised be You. I am among the unjust'. They contain the complete prayer that the Prophet Jonah is said to have spoken when he was hidden inside the fish. They are transmitted exactly so in the Qurān, in chapter twenty-one, called 'The Prophets', verse eighty-seven. ${ }^{36}$ The Muhammadan authors write that he was sent to the city of نينوي Nineveh (thus written by Kessaeus, ${ }^{37}$ but the

36 Qurān 21:87 mentions the prophet by name, though not as Jonas, but as Dhū al-Nūn, 'the man of the fish'.

37 This concerns a work by al-Kisāà $\mathbf{1}$, the author of works of the genre 'Stories of the Prophets' living in the beginning of the 5 th/11th century (GAL G I, 350). The title re-emerges as 
author of مصابي القلوب gives the name of the city as نيتوي Nitove 38 with the

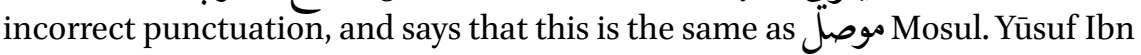
'Abd al-Lațîf ${ }^{40}$ has شهر نيلوس 'the city of Nilus', for which read:نينوس Ninos) and says that, in order to avoid the punishment that had been announced to them by the god, he had fled in a state of doubt and anger. When thereupon a tempest had arisen and lots were cast to see who should be thrown into the sea, the lot fell on Jonah. However, he was caught by a fish, in which he dwelt for forty days, till he was able to placate the irate god with these prayers, or rather with this confession, and he was returned to our open air. The words that occupy the entire surface of the outer margin of the seal show, first, this formula: بس إسمن إس الله الرمن الرحيم, 'in the name of God, the most merciful' (words that are usually [p. 244] placed before each Süra), and then they show the complete chapter of the Qur'ann, which, as you can see, is not too long. It is the antepenultimate chapter of the entire book, number one hundred and twelve, and it contains these words, with which the Muhammadans in particular fulminate against the Christians, and that they frequently take in their mouth, divided into four verses:

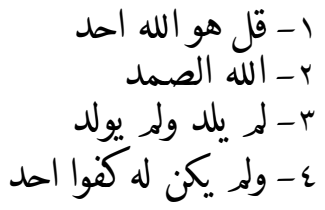

'1. Say (that is: to the infidels, or to those who ask You your opinion about God) God is one. 2. God is eternal. 3. He has no offspring; he is no offspring. 4. And no one is equal to Him. The Muhammadans hold this Süra in great honour, in such a way that several of them place it on the level of one third of the entire

Historia sacra seu vitae Prophetarum a creatione usque ad Muhammedem juxta Muhammedanorum traditionem, auctore Kessaeo in the auction catalogue of Reland's Oriental manuscripts collection (1761), p. 4, in-quarto, No. 2. Kessaei Historia Sacra is also mentioned as ms Reland No. 9 in the 'Index' of Reland, De religione Muhammedica of 1705 , and No. 10 in the edition if 1717 , on one of the unnumbered pages at the end of the volume under the heading 'Index codicum Orientalium manuscriptorum, quos citavimus, \& quibus usi sumus ...' It is now Bonn, Universitäts- und Landesbibliothek, So 7, see Appendix 2, A qua 2, in the present volume.

38 A manuscript from Reland's own collection, see No. 24 in the 'Index' of De religione Muhammedica. Utrecht, 1705, in 'Index'. The Persian text is Mașābịh al-qulüb by Abū Sacīd al-Ḥasan b. al-Ḥusayn, known as al-Shīī al-Sabzavāri, see Āghā Bozorg, al-Dharīa, vol. 21, p. 9o. The manuscript that Reland used (CCO $2707=$ vol. 5, pp. 274-275: Ms Utrecht 44) is now Utrecht, University Library, MS 1471 (1 E 2O), see <https://utrechtuniversity.on.worldcat. org/oclc/1004377427>, and the contribution by Bart Jaski in this volume.

39 Thus, in Utrecht, University Library, MS 1471, fol. 193a (chapter 44).

40 This refers to the Turkish Subhat al-akhbār, originally a historical pedigree by Yūsuf b. 'Abd al-Latịf. The manuscript is now Leiden, University Library, Acad. 182, and Reland quotes from fol. 15a. See Schmidt, Catalogue of Turkish Manuscripts. Minor Collections, pp. 202-203. 
Qur'ān. That shows clearly what the use of this seal was, and why these words were chosen for the inscription on it. Place it back in your Treasury, and keep it as an example of Arabic calligraphy and art. As the viewing of it was a most pleasant task for me, I have no doubt that it will [p. 245] be a great joy for other onlookers as well. When, in the meantime, something with a similar form of writing arrives in your hands, I wish you to think of Reland and give me either a print-off or, preferably, the original seal. Farewell, most kind De Wilde, and love me.

Thus, written in Utrecht on 18 [month not mentioned] 1706.

\section{$\S 7 \quad$ The Twelve Leaders of the Persians Inscribed on a Seal}

The fourth seal, which has been sent to me by the Most Noble Gentleman Henricus Hadrianus vander Marck ${ }^{41}$ contains, apart from the proper name of the person who used it, ${ }^{42}$ the names of the twelve leaders, or imams, whom the Persians believe to be the legitimate successors of Muhammad. As there are four among them who were called 'Alī, the engraver of this seal has drawn the letter at the end of the word 'Alī in a backward direction, in such a way that, written four times, it divides the surface into four areas, each of which is filled with the names of three leaders. Of these leaders or princes only the names are available in this seal. From my manuscript of the Taarich ${ }^{43}$ I will therefore add their titles to their names. ${ }^{44}$

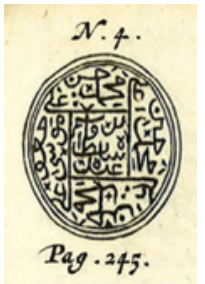

Reland, seal 4.

41 Reland writes his name as 'vander Mark'. The seal that Vander Marck showed to Reland is not mentioned in either coin catalogue.

42 Not deciphered by Reland, or by me.

43 This also concerns the Turkish text Subhat al-akhbār by Yūsuf b. 'Abd al-Lațîf, in a copy by Shahin Candi, Golius' copyist, with a continuation by Reland up to 1703. It is now MS Leiden Acad. 182. Reland has given Acad. 182 a complete Latin title-page: Genealogia ab Adamo usque ad Sultan Morad. Ab Josepho Ibn Abdollatif ex Persico in Turcicum sermonem translata juxta Sententiam Mohammedanorum. Cum Explicationibus Turcicis, ex Bibliotheca Jacobi Golii, Viri Cl. Publica auctione distracta Lugduni in Batavis XVI Octob. 1696. Adrianus Relandus. Reland quotes the names of the Shi'ite imams from ff. 18b-19b. This manuscript is mentioned in Reland's auction catalogue of 1761, p. 6, in-quarto, No. 17. Golius' Latin translation of the Subhat al-akhbār is now Ms Leiden Or. 3080: Taarich de sermone Turcico in Latinum conversum a Jacobo Golio, which manuscript was also in Reland's collection (Reland's auction catalogue of 1761, p. 3, in-folio, No. 29).

The translation simply follows Reland's text. 
1. علي المرتضى Alì al-Murtaḍā, or the one who is dear and beloved to God. His wife was Fatima, the daughter of Muhammad. [p. 246]

2. المام حسن الرضا ابو محمى Imām Hasan, who pleases God, Abū Muhammad.

3. امام حسين ابو عبداللَ Imām Ḥusayn, Abū 'Abdallāh.

4. امام ابو الحسن علي زين العابدين Imām Abū al-Hasan 'Alī, the ornament of the servants of God.

5. امام عحم الباق Imām Muhammad, who excels by wisdom.

6. امام جعفر الصادق Imām Ja'far, the just one.

7. امام موسي الكاظم Imām Mūsā, the clement one. [p. 247]

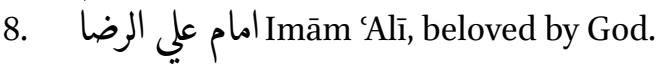

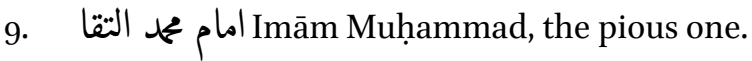

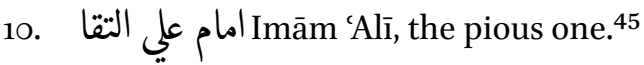

11. Imām Hasan, al-'Askarī, thus said to originate from the city of 'Askar Makrūm in Persia, where he was born. ${ }^{46}$

12. امام عجم المهدي Imām Muhammad, the guide, or the leader.

\section{$\S 8$ On the Leader al-Mahdi ${ }^{47}$}

The Persians transmit many curious facts about the last of these, al-Mahdī, who was born in the year 255 of the Muhammadan era, [p. 248] and they believe that, shortly before the end of the world, he will return victoriously among mankind, and that he will join Jesus the Messiah, so that one religion will come into being from the two religions, the Christian and the Muhammadan ones. Among the Muhammadans, there are quite a number of people who have falsely impersonated him. D'Herbelot can be consulted about them in his Bibliothèque Orientale. ${ }^{48}$ Not long ago I saw in the Treasury of Jacob de Bary, which I have mentioned before, a square leaf of silver, which I herewith show in copper engraving No. 5 , and in which this al-Mahdī is mentioned.

45 Reland is mistaken about the Arabic titles, the epithets, of the ninth and tenth imäms. They are Muhammad al-Taqī and 'Alī al-Naqī, respectively. The text in MS Leiden Acad. 182, fol. 19b, from which Reland worked, is correct, however.

46 Both Medina and Samarra are usually mentioned as his place of birth. Legend has it that he was born in the military camp in Samarra, hence his name al-'Askarī.

$47 \quad$ Reland has $\S 7$ twice.

48 Here Reland largely follows d'Herbelot, Bibliothèque orientale, p. 531, s.v. Mahadi. 


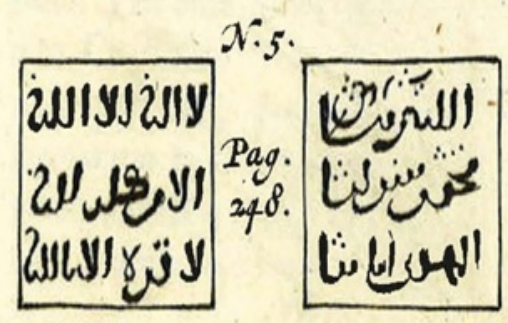

Reland, seal 5 .

On one side it contains the following words الله ربنا|محم رسولنا المهدي امامنا. This means 'God is our Lord. Muhammad is the messenger of God who was sent to us. Al-Mahdī is our leader'. On the other side it has three formulas that the Arabs call الكلمات الطيبات, 'the good words, about which Shihāb al-Dīn Abū al-Abbās ibn Aḥmad Ibn [p. 249] Yūsuf al-Aqfahsī has written a book, of which I own a manuscript:49 لا اله الا الله |الامركله لله |لا قوة الا بالله which means "There is no God but God. All command belongs to God. There is no power except in God.50

\section{§ 9 On the Seals of Private Persons, and on the Seal of the Turkish Emperor}

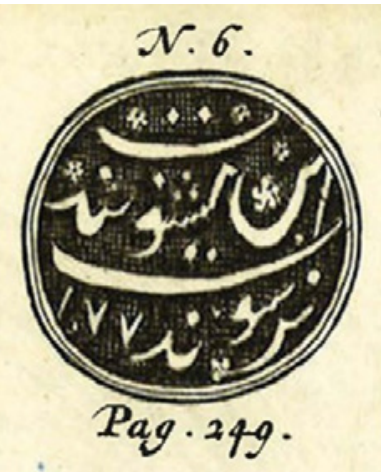

Reland, seal 6.

49 Reland's manuscript, which is now ms Leiden Acad. 29, contains two texts by Ahmad b. 'Imād al-Dīn al-Aqfahsī (d. 808/1405), GAL G II, 94: (1) Tashïl al-maqāṣid fì zuwwār al-masāğ id and (2) al-Qawlfi tafsìr al-kalimät al-țayyibāt, to which latter text Reland refers here. It is ms Reland No. 7, in the 'Index' at the end of De Religione Muhammedica; see also Appendix 2, A qua 9. The two texts in Ms Leiden Acad. 29 (2) are copies by Shahin Candi, Golius' copyist, from two texts in another Golius manuscript, that is now Leiden, University Library, Or. 1284. See Voorhoeve, Handlist, p. 274. Ms Leiden, Acad. 29, p. 196. 
زشو ثنديت:The seal that is illustrated as No. 6, contains the following words ابن كسنو ثنديت, Narshū Pandit, son of Kisnū Pandit, which is followed by the year 1077 of the Muhammadan era, which is 1666 in our era. It was, therefore, the seal of that Narshū. The word Pandit ثنديت, means in Malay 'literate, copyist, doctor'. Narshū and Kisnū are the names taken by rivers of India, or rather by the spirits that are believed to reign over them. All the seals (sigilla) of the Persians and Arabs are organized more or less in this way, and the words should, for the greater part, be read upwards from below. I do not have other examples of these here, but instead I do own the seal of the Turkish emperor Murad IV (herewith illustrated as No. 7) [p. 250], taken from a letter of the year 1632 that was addressed to the illustrious and powerful States of Holland, and that is in manuscript. ${ }^{51}$

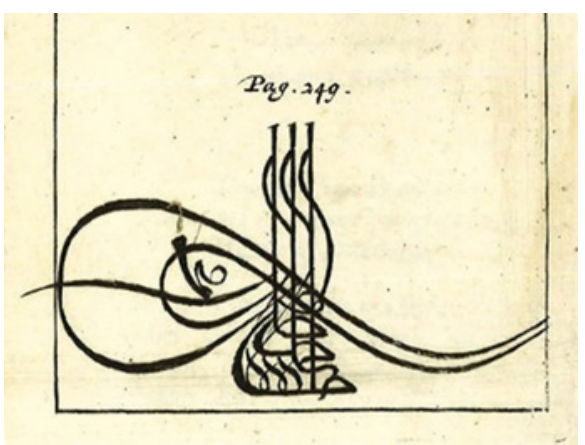

Reland, seal 7 .

Anybody can easily detect the traces of the letters of the words مراد خان Murād Khān in this seal. On the left side, as seen by the reader, two letters can be read that stand for the words مظفر دايما, forever victorious. ${ }^{52}$ The name of the emperor is written in the same way on coins, which I could add here (since

$5^{1}$ Reland refers to an authenticated copy of an Ahdnäma, in this case the trade agreement between Sultan Murad IV and the States-General of the Dutch Republic, dated 1043 (1633), in his own collection. The manuscript itself is now Ms Leiden Acad. 197. That manuscript no longer has the tughra that Reland gives as his seventh specimen. However, Reland also owned the copy of the 'Ahdnäma that was made by Golius' copyist Shahin Candi, which is now Leiden, University Library, Or. 3083. Either the original tughra of MS Leiden Acad. 197, was detached for some reason, or it was copied from Shahin Candi's copy, Ms Leiden Or. 3083, fol. ib [Fig. 13.5]. Reland may have kept the original document when engaged in translating for the States-General. See also the article by Arnoud Vrolijk in the present volume.

52 Reland's typographer has erroneously inverted the order of the words: ضايما مظف he, or Reland, also misspelled the word dāiman by writing it with a $d \bar{a} d$ instead of a $d \bar{a} l$. 
I own them), if I were not of the opinion that the writing of the letters in this larger seal is much clearer.

The end.

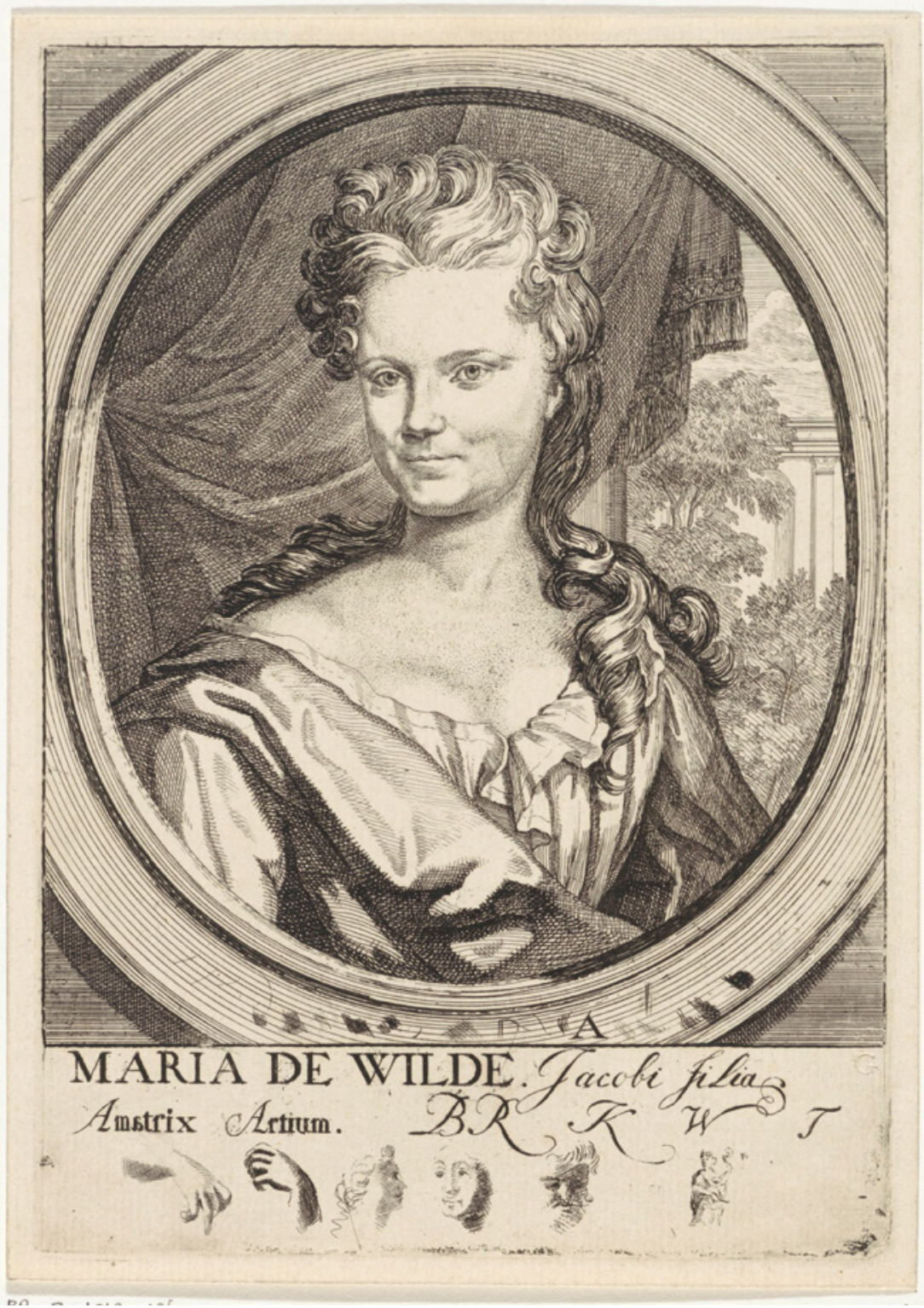

FIGURE 13.1 Self portrait of Maria de Wilde. Original etching in the Rijksmuseum, Amsterdam, RP-P-1910-186o 


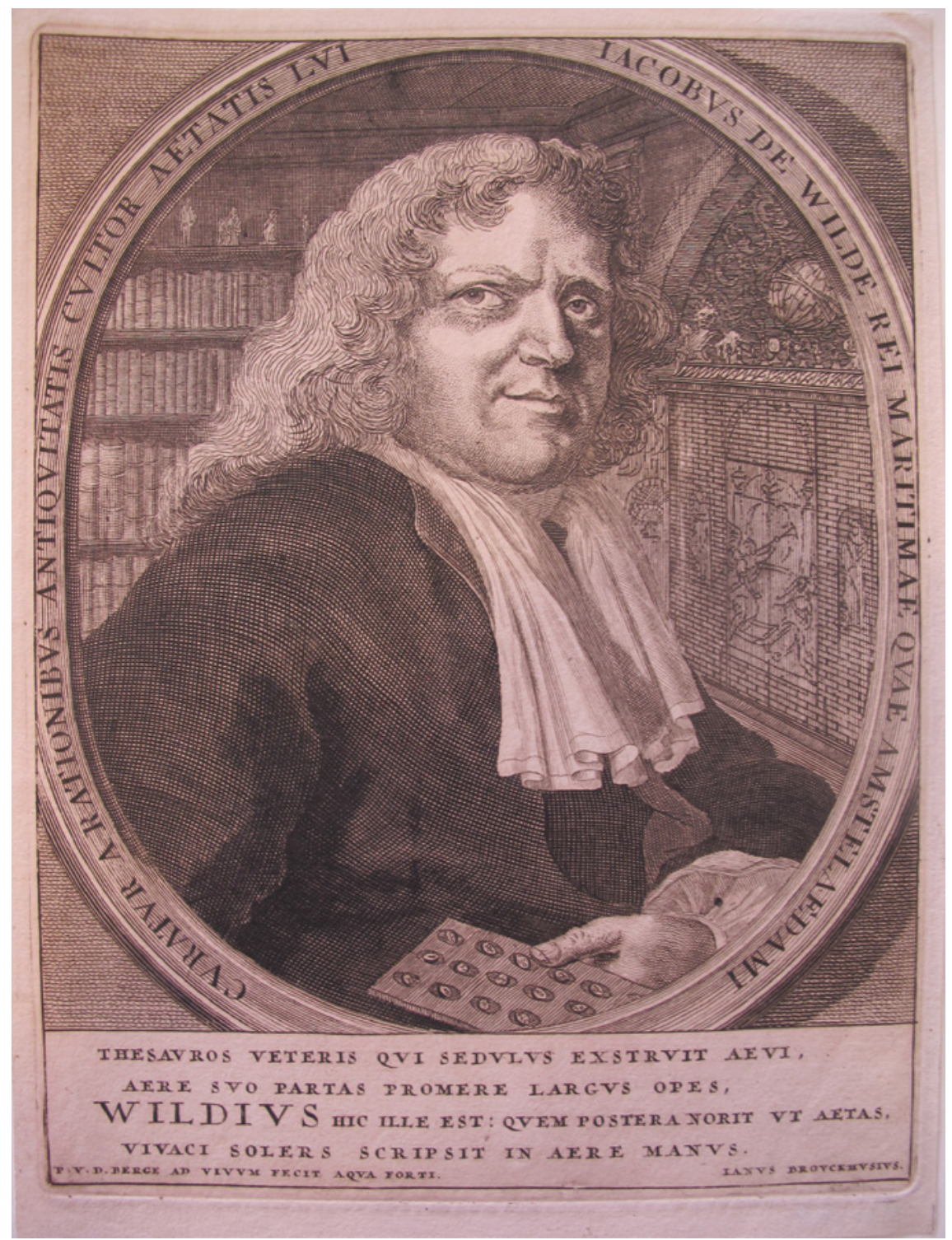

FIGURE 13.2 Portrait by Pieter van den Berge of Jacob de Wilde holding the tray of a dactyliotheca with gems. Copper engraving. From an original in Leiden, University Library, Singer 33543 suppl. 


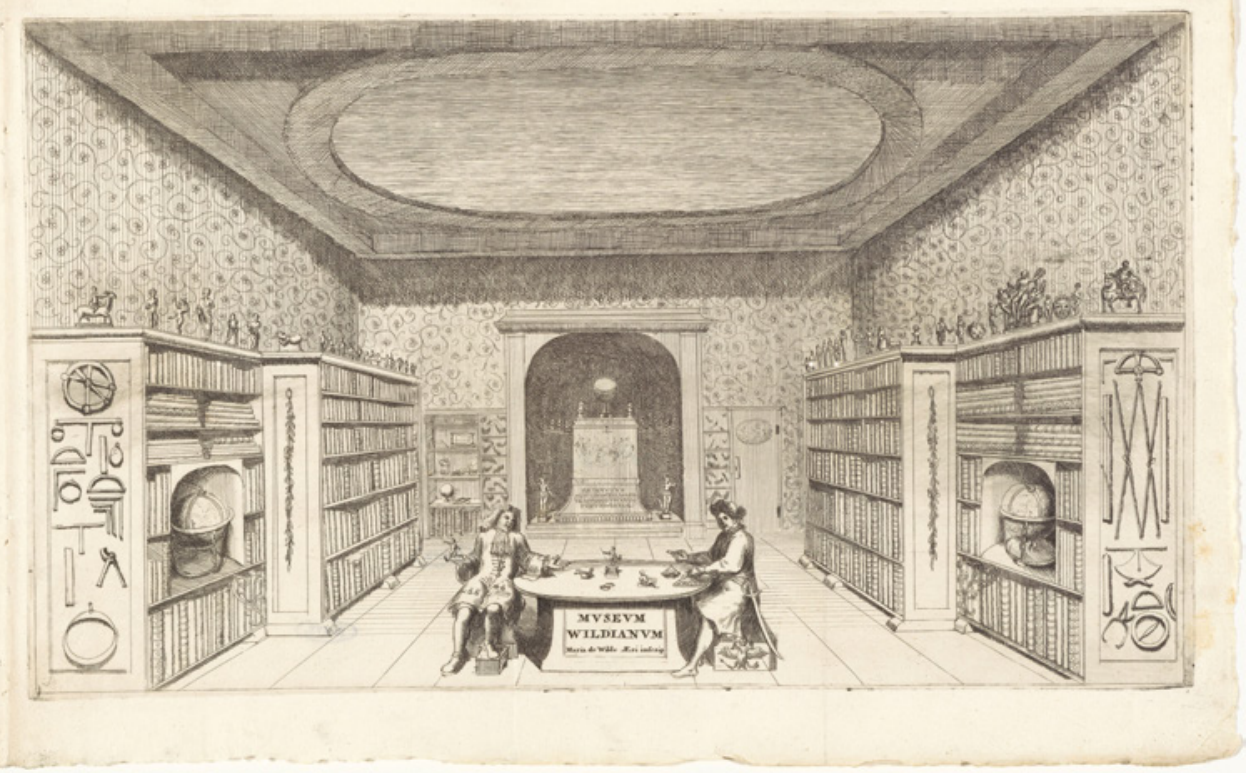

The Museum Wildianum is visited by Czar Peter the Great. Jacob de Wilde explains pieces of his collection to the royal visitor. Etching by Maria de Wilde, published in [De Wilde], Signa antiqua, from an original in the Rijksmuseum in Amsterdam, RP-P-1938-1300

\section{DISSERTAT. XIII. DE}

aequalibus fpatiis literas ubique exhibeat, illas hic Tibi extricatas, \& co ordine, quo nos vulgo characteres Arabicos difponcre folemus, exhibebo: ita ut conferens literas cum literis ductus non multum diverfos obfervare, eoque magis admirari artificium fcriptionis in gemma Tua, poffis. En Tibi ipfa verba Ara-

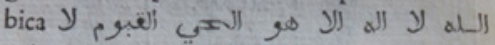

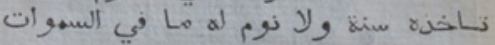

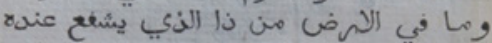

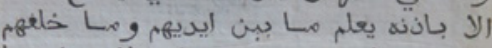

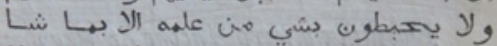

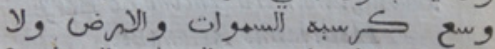

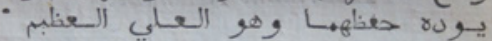
Quac Latine ita fonant. Deus: Non eft praeter illum Deus alius. Hic ef qui vivit, o in aeternum permanet, quem nulla dormitatio, nullus fommus, occupat. Hujuseft, quodconque coeli $\mathrm{O}$ terra complectuntur. Quis eft, qui co invito culpam altcrius deprecabitur? Ille eft, qui praefentia novit $\odot$ futura; quum homines nil fciant, nift quod ipfe voluerit. Thronus ejus tam late patet quam coeli $\sigma$ terra, quorum omnium confervatio nequaquam ipfief oneri. Hic of tille excel/as o magnus. Egregiam, dices, defcriptionem omnipotentiae \&. majeftatis divinae! Ita eft, Nobiliffime Vir: idque

\section{FIGURE 13.4}

The Āyat al-Kursī in seal 1. Example of the typography of Arabic, so detested by Reland, taken from his essay on gems and seals (Utrecht 1708), p. 236. Ter Lugt collection, Leiden 


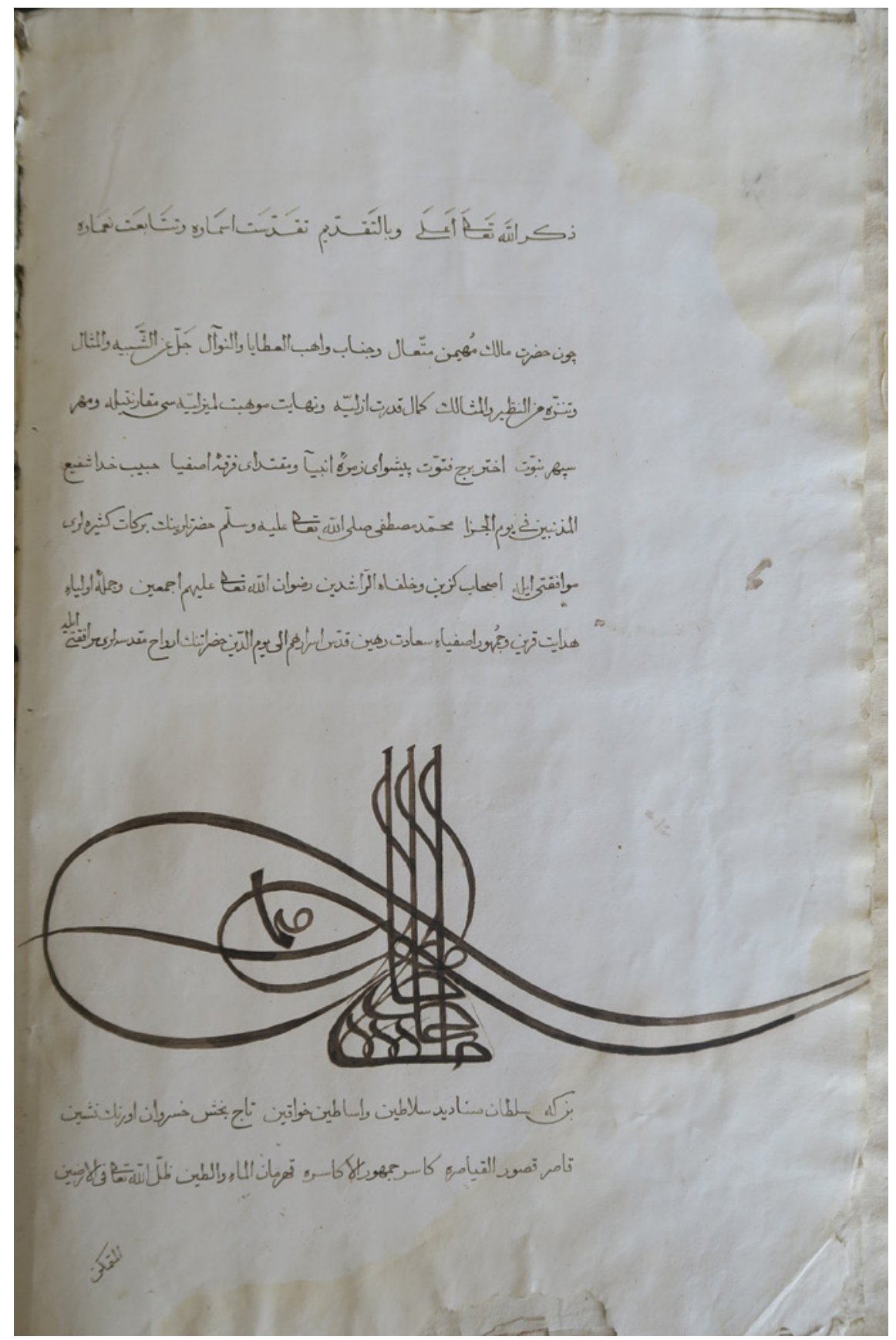

FIGURE 13.5 The Tughra of Sultan Murad IV in a copy by Shahin Candi of an Ahdnāma, treaty, of 1633. From an original in Leiden University Library, Or. 3083, f. $1 \mathrm{~b}$ 


\section{Bibliography}

\section{Sources}

[Bary, J. de], Catalogus numismatum antiquorum ex auro argento et aere, nobiliss. viri Jacobi De Bary quorum publica auctio habebitur in aedibus defuncti Amstelodami, ad mensem aprilem vel majum anni 1730. Dies Auctionis per publicas novellas accuratius indicabitur (no place, date or publisher).

Brandt, K. and J. Brandt, Poëzy, Amsterdam, B. Visscher, G. Slaats and P. Visser, 1725.

Herbelot, B. d', Bibliothèque orientale, ou dictionnaire universel, contenant généralement tout ce qui regarde la connaissance des Peuples de l'Orient, Paris, Compagnie des Libraires, 1697 .

Le Clerc, J., Bibliothèque Choisie pour servir de suite à la Bibliotheque Universelle, tomes XI-XII, Amsterdam, Henri Schelte, 1707.

Leibniz, G.W., Sämtliche Schriften und Briefe, Reihe I, Allgemeiner, politischer und historischer Briefwechsel, Transkriptionen 1711, http://www.nlb-hannover.de/ Leibniz/Leibnizarchiv/Veroeffentlichungen/Transkriptionen1711roh.pdf (accessed 22 July 2019).

[Marck, H.H. vander], Bibliotheca Marckiana sive Catalogus librarum, quos summa cura \& maximis sumptibus sibi comparavit Henricus Hadrianus vander Marck [...], Hagae-Comitum [The Hague], Petrus de Hondt, 1727.

[Marck, H.H. vander], Series numismatum antiquorum, ex auro, argento, et aere, Romanorum et Graecorum, quae magnis sumptibus congessit Henricus Adrianus à Mark, dominus in Leure \&c, quae omnia vel simul venum exponuntur, vel publice per partes distrahentur, The Hague, Petrus de Hondt, 1727.

Naam-lyst van een zeer keurige verzameling ... boeken.... alles nagelaten by wylen ... Jan Hubertus Relandt ... waar achter volgt Catalogus codicum manuscriptorum Arabicorum, Persicorum ... quibus omnibus quondam usus est ... Hadrianus Relandus, Utrecht, Willem Kroon and Gijsbert van Paddenburg, 1761.

Reland, A., Exercitatio Philologico-Theologica de Symbolo Mohammedico (Non est Deus nisi Unus) adversus quod S.S. Trinitas defenditur [...], Utrecht, François Halma, 1696.

Reland, A., Galatea. Lusus Poeticus, Amsterdam, sumtibus editoris, 1701.

Reland, A., Dissertatio de marmoribus Arabicis Puteolanis et nummo Arabico Constantini Pogonati, Amsterdam, Theodor and Henricus Bruyn, n.d. [1704?].

Reland, A., De religione Mohammedica libri duo. Quorum prior exhibet compendium theologiae Mohammedicae, ex Codice Manuscripto Arabice editum, Latine versum, \& Notis illustratum. Posterior examinat nonnulla, quae falso Mohammedanis tribuuntur, Utrecht, Willem Broedelet, 1705.

Reland, A., 'Dissertatio de Gemmis Arabicis', in idem, Dissertationes miscellaneae, Utrecht, Willem Broedelet, 1706-1708, vol. 3, pp. 231-25o. 
Reland, A., De nummis veterorum Hebraeorum qui ab inscriptarum literarum forma Samaritani appellantur, dissertationes quinque, cum tabulis aeri inscriptis, accedit Dissertatio de marmoribus Arabicis Puteolanis, Utrecht, Willem Broedelet, 1709.

Reland, A., De religione Mohammedica libri duo. Editio altera auctior, Utrecht, Willem Broedelet, 1717 .

[Wilde, J. de], Selecta numismata antiqua ex Museo Jacobi de Wilde, Amsterdam, sumptibus auctoris, 1692 .

[Wilde, J. de], Signa antiqua e Museo Jacobi de Wilde veterum poetarum carminibus illustrata et per Mariam filiam aeri inscripta, Amsterdam, sumptibus auctoris, 1700.

[Wilde, J. de], Gemmae selectae antiquae e Museo Jacobi de Wilde, sive L. Tabulae diis deabusque gentilium ornatae, per possessorem conjecturis, veterumque poetarum carminibus illustratae, Amsterdam, sumptibus auctoris, 1703 .

[Wilde, M. de], Abradates en Panthea, Treurspel, Amsterdam, Pieter van den Berge, n.d. [1710].

\section{Studies}

Āghā Bozorg al-Ṭihrānī, al-Dharĩa ilā tașānīf al-Shīa, Qum, Ismāîiliyān, n.d., vol. 21.

Bergvelt, E. and R. Kistemaker (eds), De wereld binnen handbereik. Nederlandse kunsten rariteitenverzamelingen, 1585-1735, Amsterdam, Amsterdams Historisch Museum, 1992.

cco = R.P.A. Dozy (et al.), Catalogus codicum Orientalium Bibliothecae Academiae Lugduno-Batavae, 6 vols., Leiden, E.J. Brill, 1851-1877.

$\mathrm{GAL}=$ Brockelmann, C., Geschichte der arabischen Litteratur, $\mathrm{G}=$ vols. $1-2$ (Leiden, E.J. Brill, 1943-1949); S = Supplement vols. 1-3 (Leiden, E.J. Brill, 1937-1942).

Grassi, V., 'Iscrizione funerarie Arabe nel Napoletano', in Agostino Cilardo (ed.), Atti des convegno sul tema Presenza Araba e Islamica in Campania (Napoli-Caserta, 22-25 novembre 1989), Napoli, Istituto Universitario Orientale, 1992, pp. 337-364 and Tav. CIV-CXXIV.

Hamilton, A., 'From a "Closet at Utrecht": Adriaan Reland and Islam', Nederlands Archief voor Kerkgeschiedenis / Dutch Review of Church History, vol. 78, no. 2, 1998, pp. $243^{-25}$.

Israel, J., Enlightenment Contested: Philosophy, Modernity, and the Emancipation of Man 1670-1752, Oxford, Oxford University Press, 2006.

Lewis, Ch.T. and Ch. Short, A Latin Dictionary Founded on Andrew's Edition of Freund's Latin Dictionary, Revised, Enlarged, and in Great Part Rewritten, first published 1879, Oxford, The Clarendon Press, $195^{8}$.

Sahas, D.J., John of Damascus on Islam: The Heresy of the Ishmaelites, Leiden, E.J. Brill, 1972.

Sarnelli, P., La Guida De Forestieri Curiosi di vedere, e di riconoscere le cose più memorabili Di Pozzoli, Baja, Cuma, Miseno, Gaeta, Ed altri Luoghi circonvicini: Spiegata 
con l'agiuto di gravi Autori, e con proprio riconoscimento [...], Naples, Michele-Luigi Muzio, 1709 .

Schmidt, J., Catalogue of Turkish Manuscripts in the Library of Leiden University and Other Collections in the Netherlands, Minor Collections, Leiden and Boston, Brill, 2012.

Schutte, O., Repertorium der Nederlandse vertegenwoordigers, residerende in het buitenland 1584-1810, The Hague, Martinus Nijhoff, 1976.

Voorhoeve, P., Handlist of Arabic Manuscripts in the Library of the University of Leiden and Other Collections in the Netherlands, 2nd edn., Leiden, Leiden University Press, 1980.

Wijngaards, A.G.M., De 'Bibliothèque Choisie' van Jean le Clerc. Een Amsterdams geleerdentijdschrift uit de jaren 1703 tot 1713, Amsterdam/Maarssen, APA-Holland Universiteits Pers, 1986.

Zuidema, E., 'Maria de Wilde', Nieuw Nederlandsch Biografisch Woordenboek, vol. 4, 1918, cols. $1457-1458$. 